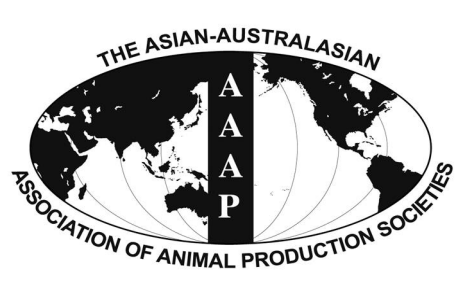

Open Access

Asian Australas. J. Anim. Sci.

Vol. 29, No. 2 : 271-279 February 2016

http://dx.doi.org/10.5713/ajas.15.0431

www.ajas.info

pISSN 1011-2367 elSSN 1976-5517

\title{
Evaluation of Honey and Rice Syrup as Replacements for Sorbitol in the Production of Restructured Duck Jerky
}

\author{
Endy Triyannanto and Keun Taik Lee* \\ Department of Food Processing and Distribution, \\ Gangneung-Wonju National University, Gangneung 210-702, Korea
}

\begin{abstract}
The aim of this study was to evaluate the potential of natural humectants such as honey and rice syrup to replace sorbitol in the production of restructured duck jerky. Each humectant was mixed at 3\%, 6\%, and 10\% (wt/wt) concentrations with the marinating solution. The values of water activity and the moisture-to-protein ratio of all of the samples were maintained below 0.75 . Jerky samples treated with honey retained more moisture than those exposed to other treatments. Among all samples, those treated with $10 \%$ sorbitol produced the highest processing yield and the lowest shear force values. The highest $L^{*}$ value and the lowest $b^{*}$ value were observed for the sorbitol-treated sample, followed by the rice syrup- and honey-treated samples. Duck jerky samples treated with $10 \%$ honey showed the highest scores for the sensory parameters evaluated. The overall acceptability scores of samples treated with rice syrup were comparable with those of samples treated with sorbitol. Microscopic observation of restructured duck jerky samples treated with honey showed stable forms and smaller pores when compared with other treatments. (Key Words: Honey, Rice Syrup, Sorbitol, Restructured Duck Jerky)
\end{abstract}

\section{INTRODUCTION}

Meat jerky is a popular snack that is easily found in retail shops worldwide. Consumption of poultry, including duck, grows annually in accordance with meat production. For example, poultry meat production grew $1.6 \%$ from 2013 to 2014, while that of beef, pork, and lamb increased $0.5 \%, 1.1 \%$, and $0.5 \%$, respectively (FAO, 2015), indicating consumer preference for poultry. An increase in overall duck meat consumption stimulated the idea of using it to develop a new similarly processed product. Duck meat has its own specific taste and positive reputation as a healthy food, and it can be processed into a unique meat jerky that is different from other conventional jerky products. Moreover, white meat showed lower fat content, cholesterol, easier to handle portions, and less religious barriers compared to red meat (Jaturasitha et al., 2008). Besides, the

\footnotetext{
* Corresponding Author: Keun Taik Lee. Tel: +82-33-640-2333, Fax: +82-33-647-4559, E-mail: leekt@gwnu.ac.kr

Submitted May 18, 2015; Revised Jul. 23, 2015; Accepted Sept. 7, 2015
}

use of tenderloin for manufacturing a duck jerky could be valuable because tenderloin has been treated as a byproduct and is cheaper than the other parts such as breasts and legs in South Korea. Therefore, duck jerky made of tenderloin can be an innovation to meet consumer demand for a healthier and less expensive duck meat product.

However, the drawbacks of manufacturing meat jerky using duck meat instead of beef and pork meat include the soft texture, pale colour, and specific odour. An appropriate choice of humectant is therefore a prerequisite for preserving the intermediately moistened texture of such jerky products. Honey is a well-known traditional food that contains around 200 nutritive substances including vitamins, proteins, minerals, organic acids, flavonoids, phenolic acids, enzymes and other phytochemicals (Bertoncelj et al., 2007). It is the only natural humectant in a concentrated sugar form that is used in food preservation worldwide (FAO, 1996). Moreover, honey has been reported to provide antioxidant effects, and to protect food from oxidative deterioration due to light, heat, and some metals (Gheldof and Engeseth, 2002; McKibben and Engeseth, 2002). As a natural 
antioxidant, honey also provides health benefits, such as antimicrobial and antiviral activities, reduction of the risk of heart and gastrointestinal diseases, and wound healing (Nagai et al., 2006).

Rice syrup is also a natural humectant, consisting of dextrin, maltose, maltotriose, and a small amount of glucose. It is produced by digesting cooked rice starch with saccharifying enzymes, followed by sieving and evaporation of the liquid until the desired consistency is obtained. Traditionally, saccharification is achieved by sprouting barley grains in rice starch; however, industrial processes typically use enzymes purified from bacterial or fungal sources.

Sorbitol is an artificial humectant that is widely used in the jerky industry for several reasons: it has a low caloric value, is well tolerated by diabetics, extends the shelf life of food products, and does not cause browning in food when heated (Emerton and Choi, 2008). Sodium chloride, glycerol, propylene glycol, sucrose, corn syrup, and dextrose are also commonly used (Michio et al., 1987). Presently, trends in consumer lifestyle indicate preference for natural products, which are regarded to be safer and healthier than synthetic ones (Rajalakshmi and Narasimhan, 1996). Sorbitol, as it were, is considered "unnatural" by consumers. This study aims to evaluate the physicochemical characteristics of duck jerkies treated with honey and rice syrup and compare them to those treated with sorbitol at different concentrations.

\section{MATERIALS AND METHODS}

Preparation of restructured duck jerky samples

Duck meat samples (tenderloin with $\mathrm{pH} 6.00 \pm 0.11$ ) were purchased from a local company (90 Ori-Q, Sonja Ryong Food, Pyeongchang, Korea). Restructured duck jerky is manufactured according to the process illustrated in Figure 1 and the recipe listed in Table 1. Tenderloin was collected from slaughtered ducks, and frozen at $-18^{\circ} \mathrm{C}$ until experiments were conducted, usually within $2 \mathrm{~d}$. The frozen meat was thawed at $5^{\circ} \mathrm{C}$ for $24 \mathrm{~h}$ prior to processing. The $\mathrm{pH}$ value of marinating solutions was $4.83 \pm 0.02$. Honey (Acacia honey, Nonghyup National Agricultural Corp. Fed., Seoul, Korea), rice syrup (Ssalyeot, Ottogi Co., Ltd., Gangnam, Korea), and sorbitol (Sorbitol powder, Taewon Food Industry Co., Ltd., Ansan, Korea) were used as humectants. Each humectant was added at 3\%, 6\%, and 10\% (wt/wt) of the weight of raw meat. All subcutaneous and intramuscular fat were trimmed off, and meat was ground for 5 min using PM-85 (Mainca, Granollers, Barcelona, Spain) fitted with a plate of 8-mm mesh. Subsequently, ground meat was marinated for $10 \mathrm{~min}$ in various solutions.

The mixture from each treatment was placed in different stainless bowls. The batter was stuffed into a jerky gun (370111-W, Weston Products, Strongsville, OH, USA) and then

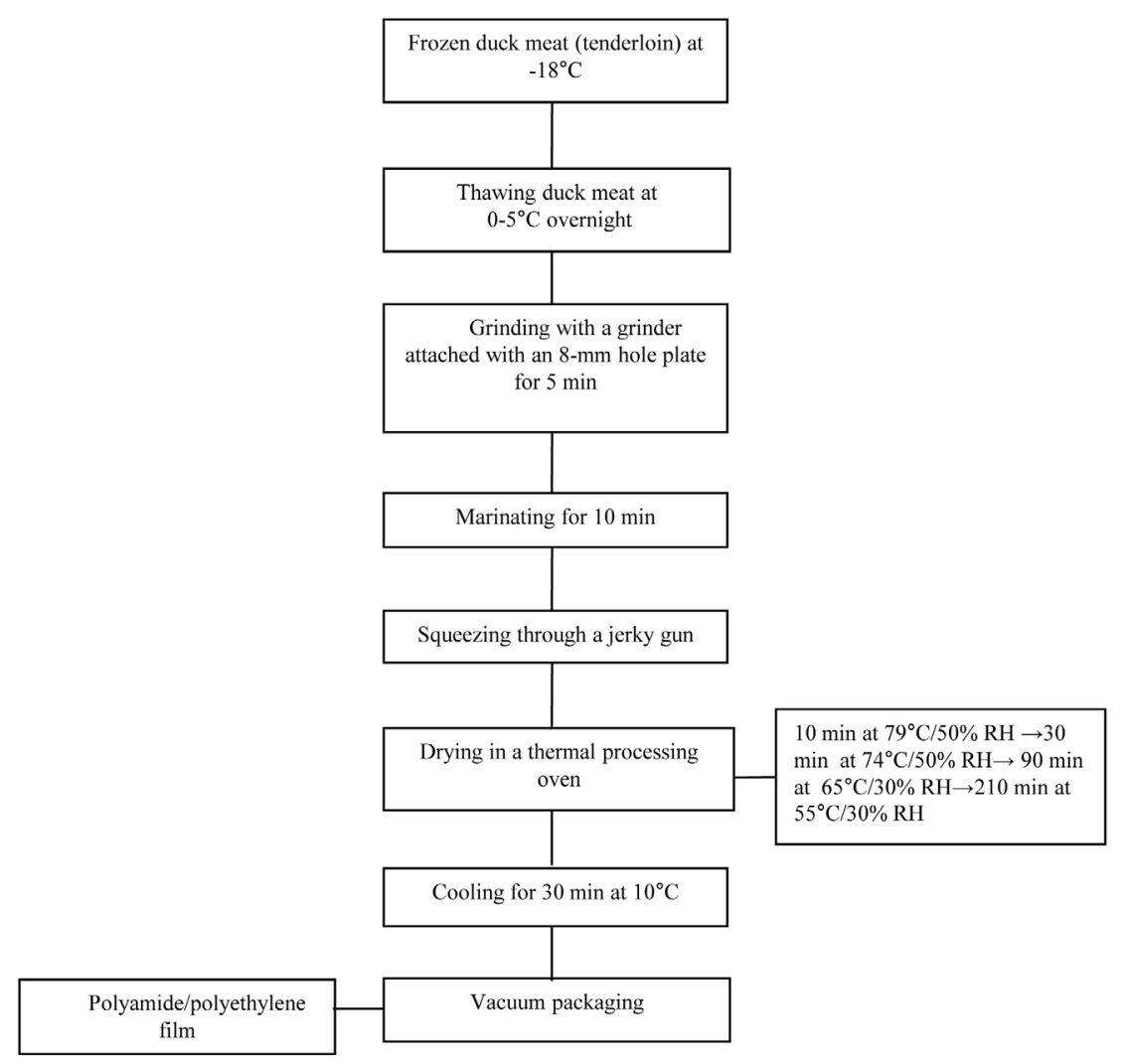

Figure 1. Manufacturing process of restructured duck jerky. 
Table 1. Recipe for restructured duck jerky

\begin{tabular}{lc}
\hline Ingredients & Formulation $(\%, \mathrm{wt} / \mathrm{wt})$ \\
\hline Duck meat & 100.00 \\
Water & 2.60 \\
Salt & 1.32 \\
White pepper & 0.19 \\
All spices & 0.09 \\
Garlic powder & 0.22 \\
Ginger powder & 0.14 \\
Ascorbic acid & 0.08 \\
Soybean sauce & 3.78 \\
Sugar & 1.89 \\
Paprika powder & 0.43 \\
Smoke oil & 0.05 \\
Onion powder & 0.24 \\
Red pepper & 0.31 \\
Black pepper & 0.14 \\
Celery powder & 0.28 \\
Tartaric acid & 0.03 \\
Nucleotide powder & 0.07 \\
Flavouring powder & 0.60 \\
Humectants ${ }^{1}$ & $3.0 / 6.0 / 10.0$ \\
\hline${ }^{1}$ Humectants treatments: addition of $3 \%, 6 \%$, and $10 \%$ concentrations of \\
honey, rice syrup, and sorbitol based on raw meat weight (wt/wt).
\end{tabular}

squeezed onto parchment paper in $12 \times 2 \times 0.5 \mathrm{~cm}$ pieces. The samples were dried in a thermal processing oven (FX61E1, Angelo Po, Modena, Italy) according to the following conditions: $10 \mathrm{~min}$ at $79^{\circ} \mathrm{C} / 50 \%$ relative humidity $(\mathrm{RH}), 30$ min at $74^{\circ} \mathrm{C} / 50 \% \mathrm{RH}, 90 \mathrm{~min}$ at $65^{\circ} \mathrm{C} / 30 \% \mathrm{RH}$, and 210 min at $55^{\circ} \mathrm{C} / 30 \% \mathrm{RH}$, before cooling at $10^{\circ} \mathrm{C}$ for $30 \mathrm{~min}$. After drying and cooling process the restructured duck jerky samples were vacuum packed in a polyamide/polyethylene film with $\mathrm{O}_{2}$ permeability at $47 \mathrm{~cm}^{3} / \mathrm{m}^{2} \cdot \mathrm{d} \cdot \mathrm{atm}$ (Jinsung Chemical Co., Ltd., Busan, Korea).

\section{Water activity $\left(a_{\mathrm{w}}\right)$}

Five grams of duck jerky were cut into small pieces using a pair of sharp scissors. The pieces were placed in an aluminium cup, and water activity $\left(a_{\mathrm{w}}\right)$ was determined using a bench top water activity meter (Aqua Lab 4 TE, Decagon Devices Inc., Pullman, WA, USA) that had been calibrated at $25^{\circ} \mathrm{C}$ with an unsaturated solution of $\mathrm{NaCl}$, the $a_{\mathrm{w}}$ of which is 0.76 .

\section{Moisture-to-protein ratio}

Moisture-to-protein ratio (MPR) was determined by dividing the moisture content by the protein content of sample (AOAC, 2007). For the determination of moisture content, five grams of finely chopped samples were dried in an aluminium dish using a halogen moisture drying machine (US/SX-2000, Tekmar-Dorhmann, Mason, OH, USA). The weight difference of samples before and after drying was determined in triplicate on each duck jerky treatment. The protein content was determined by using a Kjeldahl nitrogen analyzer (KjelFlex K-360, Buchi Labortechnik, Flawil, Switzerland), in accordance with the Kjeldahl procedure. A sample of $0.5 \mathrm{~g}$ was placed in a digestion tube along with two tablets containing potassium sulphate and selenium, mixed with $20 \mathrm{~mL}$ concentrated $\mathrm{H}_{2} \mathrm{SO}_{4}$, and then heated for $1.5 \mathrm{~h}$. After cooling for $30 \mathrm{~min}$ at ambient temperature, the solution was titrated at $20^{\circ} \mathrm{C}$ with $20 \mathrm{~mL} \mathrm{HCl}$ in an 877 Titrino Plus titration machine (Metrohm, Herisau, Switzerland). Data were recorded automatically after the $\mathrm{pH}$ reached 3.8 .

\section{pH value}

The $\mathrm{pH}$ value was measured in triplicate using a digital pH meter (Sg2-ELK, Mettler Toledo Co., Ltd., Greifensee, Switzerland). Duck jerky was cut into small pieces, and ground in $40 \mathrm{~mL}$ distilled water using a laboratory blender (Waring Commercial, Torrington, CT, USA) operated at low and high speeds for $40 \mathrm{~s}$ each. Ten grams of the resulting slurry were then homogenized using a T 18 Ultra-Turrax homogenizer (IKA Werke GmbH \& Co., Staufen, Germany), and $\mathrm{pH}$ was measured in triplicate. The $\mathrm{pH}$ meter was calibrated at $25^{\circ} \mathrm{C}$ with standard buffers $\mathrm{pH} 4.0,7.0$, and 10.0 .

\section{Processing yields}

Processing yields were determined using the method of Han et al. (2011). Processing yields were calculated by dividing the sample weight after drying by the weight before drying as follows:

$$
\begin{aligned}
& \text { Processing yields }(\%) \\
& =\frac{\text { Jerky weight after drying }(\mathrm{g})}{\text { Marinated meat weight before drying }(\mathrm{g})} \times 100
\end{aligned}
$$

\section{Shear force}

Shear force $\left(\mathrm{N} / \mathrm{cm}^{2}\right)$ was determined according to Faucitano et al. (2008). Briefly, duck jerky was cut into $2 \times 2 \times 0.3 \mathrm{~cm}$ size, and shear force was measured in crosssectional square cores at approximately the same location in each of 10 samples. Shear force measurements were carried out using a texture analyzer (TA.XT.plus, Texture Technologies Corp., Scarsdale, NY, USA) equipped with a heavy duty platform/blade set (HDP/BS) probe at a height of $6 \mathrm{~mm}$, and $50 \%$ strain. Samples were sheared crosswise with a $30-\mathrm{kg}$ cell at a speed of $1.5 \mathrm{~mm} / \mathrm{s}$. The probe was calibrated prior to measurement.

\section{2-Thiobarbituric acid reactive substance (TBARS)}

The 2-Thiobarbituric acid reactive substance (TBARS) analysis was conducted using the method described by Sinhuber and Yu (1977). Briefly, $0.4 \mathrm{~g}$ jerky was weighed into a $30 \mathrm{~mL}$ screw-capped pyrex tube (Pyrex, Bentonville, 
AR, USA), and mixed with 2 to 3 drops of antioxidant, 3 $\mathrm{mL}$ 2-thiobarbituric acid, and $17 \mathrm{~mL}$ trichloroacetic acid (TCA)-HCl. The antioxidant solution was composed of mixtures of $0.3 \mathrm{~g}$ butylated hydroxyl anisole and $5.4 \mathrm{~g}$ propylene glycol, or of $0.3 \mathrm{~g}$ butylated hydroxyl toluene and $4.0 \mathrm{~g}$ Tween 20 . TCA-HCl was prepared by dissolving $25 \mathrm{~g}$ trichloroacetic acid in $60 \mathrm{~mL} 0.6 \mathrm{~N} \mathrm{HCl}$, and then using distilled water to make the volume up to $1,000 \mathrm{~mL}$. Treated samples were then vortexed, and incubated for $30 \mathrm{~min}$ at $100^{\circ} \mathrm{C}$ in a boiling water bath to develop colour. The sample was cooled in cold water for $10 \mathrm{~min}$, and $5 \mathrm{~mL}$ of the supernatant was transferred to a $10 \mathrm{~mL}$ glass tube. The supernatant was mixed with $2 \mathrm{~mL}$ chloroform, and centrifuged for $15 \mathrm{~min}$ at 3,500 rpm. Finally, absorbance at $532 \mathrm{~nm}$ of the cleared supernatant was measured against a blank containing all reagents except the sample. TBARS was determined in triplicate and calculated according to;

TBARS (mg MDA/kg sample)

$=\frac{(\text { Absorbance sample }- \text { Absorbance blank }) \times 46}{\text { Sample weight }(\mathrm{g}) \times 5}$

\section{Surface color}

The surface colour of duck jerky samples was measured according to the CIE L* (whiteness), a* (redness), and $\mathrm{b}^{*}$ (yellowness) system using a colorimeter (CR-400, Konica Minolta Sensing Inc., Tokyo, Japan), and then standardized to a white calibration plate $(\mathrm{Y}=93.7, \mathrm{x}=0.3132$, and $\mathrm{y}=$ 0.3192 ). Surface colour was measured six times for each treatment.

\section{Microstructure}

Restructured duck jerky was examined microscopically following the method described by $\mathrm{Hu}$ et al. (2011), with some modifications. Approximately $5 \mathrm{~g}$ of sample were covered with aluminum foil, although small holes were made to allow air circulation. Samples were frozen at $-18^{\circ} \mathrm{C}$ for $24 \mathrm{~h}$, and then freeze-dried using Clean Vac (Hanil Science Industrial Co., Ltd., Incheon, Korea). Dried jerky was fractured using a scalpel knife into pieces approximately $1 \times 1 \times 0.5 \mathrm{~mm}$. Samples were then attached to the scanning electron microscope (SEM) stub with doublesided cellophane tape, and coated for $50 \mathrm{~s}$ at 0.05 mbar with $21.4 \mathrm{~g} / \mathrm{cm}^{3}$ platinum (Pt) using an SPI-Module Sputter Coater (Leica EM SC005, Leica Mikrosysteme GmbH., Vienna, Austria). Sections of the sample were examined using Inspect F50 Quanta (FEI, Tokyo, Japan), a scanning electron microscope, at an accelerating voltage of $5.00 \mathrm{kV}$, $20,000 \times$ magnification, and $10.4 \mathrm{~mm}$ working distance.

\section{Sensory evaluation}

Sensory evaluation was performed by 11 to 12 panelists of Food Packaging Laboratory members who have experience in the quality assessment of meat jerky. Panelists evaluated samples in terms of colour, flavour, tenderness, sweetness, and overall acceptability using a 9-point hedonic scale described in Meilgaard et al. (1999). Samples were placed on polypropylene trays, tagged with three-digit random numbers, and presented to panelists under threewavelength lamps at 1,200 lx. Panelists were asked to rinse their mouths between tastings using bottled water containing a few drops of apple vinegar (Ottogi Co., Ltd., Anyang, Korea).

\section{Statistical analysis}

Data were analysed using SPSS Statistics 12.0 for Windows Evaluation Version (SPSS, 2012). Statistical significance at $\mathrm{p}<0.05$ was tested by one way analysis of variance and Duncan's multiple range tests.

\section{RESULTS AND DISCUSSION}

\section{Water activity $\left(a_{\mathrm{w}}\right)$ and moisture content}

The values of $a_{\mathrm{w}}$ and moisture content of restructured duck jerky treated with different concentrations of honey, rice syrup, and sorbitol are shown in Table 2 . The measured $a_{\mathrm{w}}$ values in all samples ranged between 0.709 and 0.744 , indicating that the restructured duck jerky samples were

Table 2. Comparison of water activity, moisture content, and moisture-to-protein ratio of restructured duck jerkies prepared with honey, rice syrup, and sorbitol

\begin{tabular}{lcccc}
\hline Treatments & Concentration (\%) & $a_{\mathrm{w}}$ & Moisture content (\%) & Moisture-to-protein ratio \\
\hline Honey & 3 & $0.744 \pm 0.00^{\mathrm{a}}$ & $36.15 \pm 0.04^{\mathrm{a}}$ & $0.745 \pm 0.01^{\mathrm{a}}$ \\
& 6 & $0.733 \pm 0.00^{\mathrm{bc}}$ & $35.01 \pm 0.28^{\mathrm{bc}}$ & $0.730 \pm 0.03^{\mathrm{a}}$ \\
Rice syrup & 10 & $0.709 \pm 0.00^{\mathrm{g}}$ & $34.66 \pm 1.00^{\mathrm{abc}}$ & $0.720 \pm 0.03^{\mathrm{a}}$ \\
& 3 & $0.733 \pm 0.00^{\mathrm{bc}}$ & $33.93 \pm 1.26^{\mathrm{bcd}}$ & $0.745 \pm 0.02^{\mathrm{a}}$ \\
Sorbitol & 6 & $0.729 \pm 0.00^{\mathrm{c}}$ & $33.93 \pm 1.24^{\mathrm{bcd}}$ & $0.720 \pm 0.04^{\mathrm{a}}$ \\
& 10 & $0.725 \pm 0.00^{\mathrm{e}}$ & $32.76 \pm 0.74^{\mathrm{d}}$ & $0.720 \pm 0.00^{\mathrm{a}}$ \\
& 3 & $0.735 \pm 0.00^{\mathrm{b}}$ & $33.93 \pm 0.64^{\mathrm{bcd}}$ & $0.740 \pm 0.03^{\mathrm{a}}$ \\
\hline
\end{tabular}

${ }_{\mathrm{a}-\mathrm{f}}$ Means \pm standard deviation in the same row with different superscripts are significantly different at $\mathrm{p}<0.05$. 
produced below 0.85 , which is the critical limit value for the growth of bacteria. Maintaining an $a_{w}$ below 0.85 is important for inhibiting Clostridium botulinum growth, which is tremendously toxic (McClure et al., 1994). For meat jerky, stability of $a_{\mathrm{w}}$ is also necessary to avoid quality changes during storage (Leistner, 1985). Moreover, Banwart (1989) reports that low $a_{\mathrm{w}}$ could extend the shelf life of food during storage. As reported by Quinton (1997) and Chang et al. (1996), meat jerky needs to be dried to $a_{\mathrm{w}}$ in between 0.70 and 0.85 to achieve stability. Results show that samples treated with honey could retain more moisture than those treated with the same concentration of rice syrup or sorbitol. Moreover, samples treated with $10 \%$ honey showed the lower $a_{\mathrm{w}}$ value while maintaining higher moisture content than samples treated with same concentrations of rice syrup and sorbitol $(p<0.05)$. The ability of honey to stabilize $a_{\mathrm{w}}$ has been reported by Gleiter et al. (2006) to be due to its glucose content. Moreover, we achieved far lower $a_{\mathrm{w}}$ values than those achieved by Cho and Lee (2000), who reported that $a_{\mathrm{w}}$ in beef jerky treated with honey and rice syrup ranged between 0.78 and 0.82 at $0 \mathrm{~d}$. Presumeably, this is because our samples might have been longer at a higher temperature than the previous studies. In this light, the relatively high amounts of moisture retained by $10 \%$ honey indicate that it could replace sorbitol at the same concentration. According to Lee and Kang (2003), moisture content and thermal conditions influence the tensile strength of ostrich jerky, which implies that jerky products with lower moisture content are more difficult to tear into bite-size pieces than those with higher moisture content.

\section{Moisture-to-protein ratio}

The MPR of all samples ranged from 0.705 to 0.745 (Table 2), indicating that these products can be stored with minimal microbiological risk. MPR is one of the dryness parameters that determine the shelf life of dried meat products (Konieczny et al., 2007). Borneman et al. (2009) define the MPR value of 0.75 as the upper limit for assuring microbiological safety in meat products. Our samples were in line with the industrial standard, and were not significantly affected by the concentration of humectant ( $p>0.05)$. As reported by Konieczny et al. (2007), jerky is classified as intermediate-moisture food with low fat $( \pm 3.6 \%)$ and moisture content $( \pm 20 \%)$, high protein content $( \pm 50 \%)$, relatively high amounts of table salt $( \pm 6.0 \%)$, and water activity below 0.8 .

\section{pH value}

Measured $\mathrm{pH}$ levels are listed in Table 3. The $\mathrm{pH}$ values of the samples treated with honey and rice syrup were in the range of 5.97 to 6.04 and 5.99 to 6.02 , respectively, while those of sorbitol were between 6.01 and 6.05 . These results were slightly higher than the prior study conducted by Kim et al. (2014), who reported that the $\mathrm{pH}$ values of reconstructed duck jerky without humectants were in the range of 5.66 to 5.74. In our study, the $\mathrm{pH}$ values were not significantly different among the samples at the same concentration level $(\mathrm{p}>0.05)$, except that the $10 \%$ honey sample showed a significantly lower $\mathrm{pH}$ value than the $10 \%$ sorbitol sample $(p<0.05)$. This might be related to the natural acidity as a result of the predominant fatty acid compounds such as gluconic acid (Naman et al., 2005). According to Han et al. (2011) the $\mathrm{pH}$ of semi-dried chicken jerky with humectants such as konjac, egg albumin, and isolated soy protein was measured to be in the range of 6.10 to $6.14,6.10$ to 6.17 , and 6.14 to 6.15 , respectively.

Tests did not detect significant differences in $\mathrm{pH}$ between addition of $6 \%$ and $10 \%$ honey and rice syrup $(\mathrm{p}>0.05)$. However, jerky treated with $10 \%$ sorbitol had higher $\mathrm{pH}$ than samples treated with honey at the same concentration $(\mathrm{p}<0.05)$. Interestingly, samples treated with a $10 \%$ honey had the lowest $\mathrm{pH}$ values. Indeed, the acidity might help maintain quality, as Ogahara et al. (1995) have reported that low $\mathrm{pH}$ inhibits or delays spoilage of dried meat due to mold and other microorganisms. From this

Table 3. Comparison of $\mathrm{pH}$, processing yield, shear force, and TBARS of restructured duck jerkies prepared with honey, rice syrup, and sorbitol

\begin{tabular}{lccccc}
\hline Treatments & $\begin{array}{c}\text { Concentration } \\
(\%)\end{array}$ & $\mathrm{pH}$ & $\begin{array}{c}\text { Processing yield } \\
(\%)\end{array}$ & $\begin{array}{c}\text { Shear force } \\
\left(\mathrm{N} / \mathrm{cm}^{2}\right)\end{array}$ & $\begin{array}{c}\text { TBARS } \\
(\mathrm{mg} \mathrm{MDA} / \mathrm{kg})\end{array}$ \\
\hline Honey & 3 & $6.04 \pm 0.02^{\mathrm{ab}}$ & $45.27 \pm 1.42^{\mathrm{cd}}$ & $25.46 \pm 3.54^{\mathrm{ab}}$ & $0.82 \pm 1.00^{\mathrm{a}}$ \\
& 6 & $5.99 \pm 0.03^{\mathrm{cde}}$ & $46.34 \pm 1.71^{\mathrm{bc}}$ & $22.06 \pm 3.67^{\mathrm{bc}}$ & $0.96 \pm 0.00^{\mathrm{a}}$ \\
Rice syrup & 10 & $5.97 \pm 0.00^{\mathrm{e}}$ & $46.96 \pm 1.27^{\mathrm{b}}$ & $20.05 \pm 2.57^{\mathrm{cd}}$ & $0.98 \pm 0.01^{\mathrm{a}}$ \\
& 3 & $6.02 \pm 0.00^{\mathrm{bc}}$ & $44.12 \pm 1.04^{\mathrm{d}}$ & $29.31 \pm 3.49^{\mathrm{a}}$ & $0.73 \pm 0.08^{\mathrm{a}}$ \\
Sorbitol & 6 & $6.00 \pm 0.01^{\mathrm{cd}}$ & $44.18 \pm 1.11^{\mathrm{d}}$ & $26.75 \pm 3.58^{\mathrm{ab}}$ & $0.56 \pm 0.42^{\mathrm{a}}$ \\
& 10 & $5.99 \pm 0.02^{\mathrm{de}}$ & $47.62 \pm 1.03^{\mathrm{b}}$ & $18.48 \pm 3.68^{\mathrm{cd}}$ & $0.43 \pm 0.50^{\mathrm{a}}$ \\
& 3 & $6.05 \pm 0.02^{\mathrm{a}}$ & $45.46 \pm 0.74^{\mathrm{cd}}$ & $26.66 \pm 1.16^{\mathrm{ab}}$ & $0.43 \pm 0.31^{\mathrm{a}}$ \\
& 6 & $6.01 \pm 0.00^{\mathrm{cd}}$ & $47.58 \pm 1.54^{\mathrm{b}}$ & $17.70 \pm 1.44^{\mathrm{cd}}$ & $0.43 \pm 0.16^{\mathrm{a}}$ \\
\hline
\end{tabular}

TBARS, 2-Thiobarbituric acid reactive substance.

${ }^{\mathrm{a}-\mathrm{f}}$ Means \pm standard deviation in the same row with different superscripts are significantly different at $\mathrm{p}<0.05$. 
point of view, the samples with honey added as a natural humectant showed lower $\mathrm{pH}$ value than the samples treated with sorbitol, which could positively affect to inhibit microbial growth.

\section{Processing yields}

Processing yield values of duck jerkies with different concentration of humectants added are presented in Table 3. Processing yields ranged from $44.1 \%$ to $49.4 \%$, and were positively correlated with humectants concentration. These results are in accordance with the study by Han et al. (2011), who demonstrated that application of various humectants increased processing yields of semi-dried chicken jerky. In this study, the increment in yield was greater with higher concentrations of sorbitol, and the highest yield was obtained with $10 \%$ sorbitol, even though there was no significant difference between samples treated with $6 \%$ and $10 \%$ honey, and between samples treated with honey and rice syrup at concentrations of $10 \% \quad(p>0.05)$. Thus, application of $10 \%$ honey or rice syrup could potentially increase processing yield, but not to the same extent as $10 \%$ sorbitol $(\mathrm{p}<0.05)$.

\section{Shear force}

Measurements of shear force are presented in Table 3. Our data show that higher concentration of humectant generally decreases shear force, suggesting a tender product. Consumer acceptance of meat and meat products depends to some degree on tenderness (Kim and Lee, 2003), which is commonly determined by shear force measurement (Culler et al., 1978). In this study, out of all the humectant concentrations, samples treated with $10 \%$ humectant had the lowest shear force value, which tended to decrease with the higher addition of humectants. Based on these results, $10 \%$ honey or rice syrup produces better tenderness, and could substitute for sorbitol at the same concentration.

\section{2-Thiobarbituric acid reactive substance}

Lipid oxidation, as measured with TBARS (Table 3), was not significantly different among batches $(p>0.05)$, and ranged from 0.43 to $0.98 \mathrm{mg}$ malondialdehyde $/ \mathrm{kg}$. Interestingly, incorporation of $10 \%$ honey increased TBARS reactivity, although not to a statistically significant extent. However, this result is in agreement with data from Cho and Lee (2000), which show higher TBARS reactivity in beef jerky cured with honey than in those cured in rice syrup. A prior study demonstrates that TBARS values between 0.5 and 1.0 have been suggested as the threshold for oxidized odour and samples with values above 1.0 tend to have an oxidized flavour (Sindelar et al., 2010). The TBARS values of the restructured duck jerky produced in this study were below the oxidation threshold for meat products.

\section{Surface color}

Colour as an indicator of meat quality is critical to consumers' purchase decisions (Brewer et al., 2002). Table 4 summarizes the surface colour of duck jerky manufactured with different humectants. Lightness (Commission Internationale de l'Eclairage [CIE] L*) was in the range of 24.51 to $27.15,28.23$ to 28.70 , and 29.10 to 29.47 for jerky cured in honey, rice syrup and sorbitol, respectively. Samples treated with sorbitol showed higher CIE $L^{*}$ values than those treated with rice syrup and honey, with the highest value obtained for samples treated with $10 \%$ sorbitol. Moreover, products treated with sorbitol have the highest CIE $\mathrm{L}^{*}$ value, followed by samples prepared with rice syrup and honey. Presumably, the reason is that sorbitol did not produce browning during drying, as has been reported (Emerton and Choi, 2008).

The CIE $\mathrm{a}^{*}$ values were in the range of 4.22 to 5.08 for honey, 4.04 to 4.66 for rice syrup, and 3.97 to 4.18 for sorbitol, respectively. Interestingly, samples treated with $3 \%$ honey showed the highest CIE a* values, which shows that honey can maintain the red colour of duck jerky at low concentrations. Yellowness (CIE $\mathrm{b}^{*}$ ) was in the range of 2.01 to $3.83,1.75$ to 2.57 , and 1.51 to 1.65 for the jerkies manufactured with honey, rice syrup, and sorbitol, respectively. Yellowness tended to decrease with higher concentrations of humectants. Honey treatment resulted in

Table 4. Comparison of surface color of restructured duck jerkies prepared with honey, rice syrup, and sorbitol

\begin{tabular}{lcccc}
\hline Treatments & Concentration (\%) & $\mathrm{L}^{*}$ & $\mathrm{a}^{*}$ & $\mathrm{~b}^{*}$ \\
\hline Honey & 3 & $24.51 \pm 0.70^{\mathrm{e}}$ & $5.08 \pm 0.53^{\mathrm{a}}$ & $3.83 \pm 0.31^{\mathrm{a}}$ \\
& 6 & $25.03 \pm 0.59^{\mathrm{e}}$ & $4.23 \pm 0.57^{\mathrm{bc}}$ & $2.83 \pm 0.44^{\mathrm{b}}$ \\
Rice syrup & 10 & $27.15 \pm 0.53^{\mathrm{d}}$ & $4.22 \pm 0.41^{\mathrm{bc}}$ & $2.57 \pm 0.34^{\mathrm{c}}$ \\
& 3 & $28.23 \pm 0.25^{\mathrm{c}}$ & $4.66 \pm 0.44^{\mathrm{ab}}$ & $1.97 \pm 0.42^{\mathrm{c}}$ \\
& 6 & $28.34 \pm 0.47^{\mathrm{c}}$ & $4.36 \pm 0.31^{\mathrm{bc}}$ & $1.75 \pm 0.16^{\mathrm{cd}}$ \\
Sorbitol & 10 & $28.70 \pm 0.41^{\mathrm{bc}}$ & $4.04 \pm 0.51^{\mathrm{c}}$ & $1.65 \pm 0.16^{\mathrm{cd}}$ \\
& 3 & $29.10 \pm 0.52^{\mathrm{ab}}$ & $4.18 \pm 0.27^{\mathrm{bc}}$ & $1.58 \pm 0.22^{\mathrm{cd}}$ \\
& 6 & $29.20 \pm 0.30^{\mathrm{ab}}$ & $4.06 \pm 0.37^{\mathrm{bc}}$ & $1.51 \pm 0.60^{\mathrm{d}}$ \\
\hline
\end{tabular}

${ }_{\mathrm{a}-\mathrm{f}}$ Means \pm standard deviation in the same row with different superscripts are significantly different at $\mathrm{p}<0.05$. 
more yellow colour than did treatment with same concentrations of the other humectants, even though it decreased at higher concentrations. Cho and Lee (2000), reported that beef jerky samples treated with honey had higher CIE $b^{*}$ values than samples treated with rice syrup. The addition of honey can therefore be regarded as a method of increasing the yellow colour of restructured duck jerky that is more effective than rice syrup and sorbitol treatments. Moreover, CIE b* was lower in jerky prepared with sorbitol than in meat cured with honey, and was not significantly different at different concentrations $(\mathrm{p}>0.05)$. Newman et al. (1999) described sorbitol as an odourless and almost colourless humectant. It is also worth mentioning that honey treatment is more effective in maintaining a dark red-yellow combined colour in restructured duck jerky, which results in higher consumer acceptance, than rice syrup and sorbitol treatments.

\section{Microstructure}

As shown in Figure 2, representative SEM images of various jerky samples were markedly different from each other. The pores of the restructured duck jerky samples treated with honey had stable structural forms and remained smaller than those of the samples treated with rice syrup and sorbitol. This might be attributed to honey, which might be effective in retaining moisture within the jerky during the drying process, thereby facilitating the formation of smaller and more pores than that achieved with the other treatments. In contrast, few pores were observed in samples treated with sorbitol. This observation might be linked to the fact that sorbitol does not retain moisture to the same extent as honey and rice syrup. This result is consistent with Wongwiwat and Wattanachant (2010), who showed that sorbitol forms less hydrogen bonds than fructose-based humectants. In turn, reduced hydrogen bonding might result in less moisture retained during drying.

\section{Sensory evaluation}

Results of taste tests are presented in Table 5. The sensory evaluation scores of duck jerky treated with honey
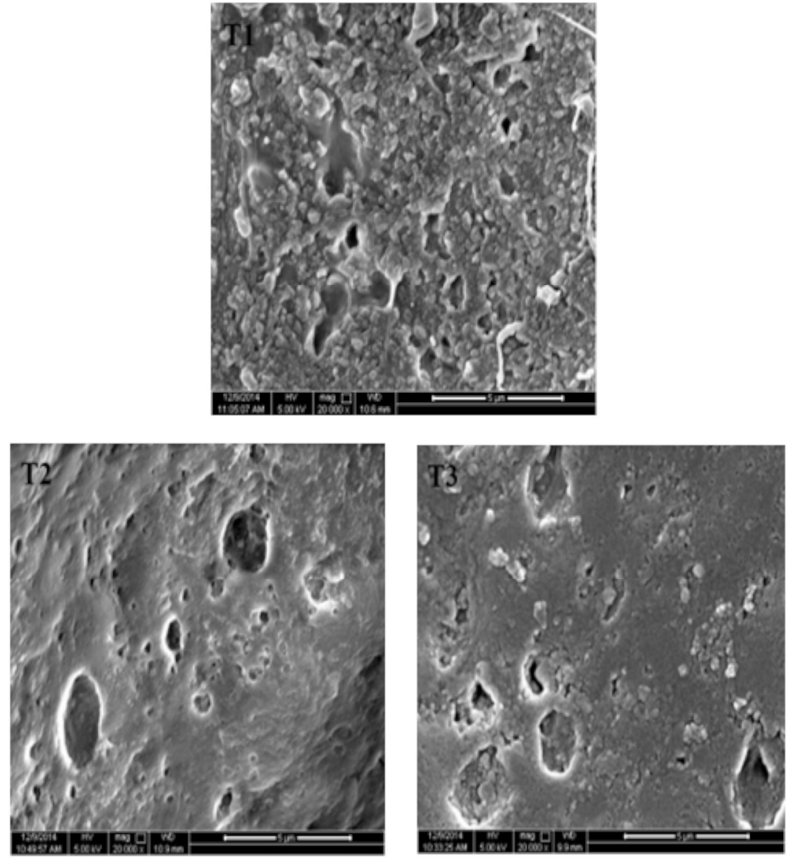

Figure 2. Typical scanning electron microscope pictures of restructured duck jerkies prepared with $6 \%$ honey (T1), $6 \%$ rice syrup (T2), and $6 \%$ sorbitol (T3) (wt/wt). Samples were coated with platinum $(\mathrm{Pt})$ at 20.000 magnification.

increased with increasing concentration of humectants $(p<0.05)$, although differences in colour and overall acceptability properties remained insignificant between $6 \%$ and $10 \%$ concentrations. Samples treated with $10 \%$ honey showed the highest scores, followed by those treated with rice syrup and sorbitol. However, the tenderness scores of the samples treated with rice syrup were lower than those of the samples treated with $6 \%$ and $10 \%$ sorbitol. Honey has been known for decades to enhance sweetness, and confer functional advantages, nutritional value, and unique flavours in wide array of food products (Antony et al., 2000). Nagai et al. (2006) detected higher hedonic response to beef, pork, chicken, and fish meat stored with honey. Honey was meant in this study to replace sorbitol, an unnatural humectant, and to increase hedonic acceptance of

Table 5. Sensory evaluations of restructured duck jerkies prepared with honey, rice syrup, and sorbitol

\begin{tabular}{lcccccc}
\hline Treatments & Concentration (\%) & Colour & Flavour & Tenderness & Sweetness & Overall acceptability \\
\hline Honey & 3 & $8.00 \pm 0.48^{\mathrm{b}}$ & $7.50 \pm 0.46^{\mathrm{c}}$ & $7.60 \pm 0.20^{\mathrm{c}}$ & $7.00 \pm 0.52^{\mathrm{d}}$ & $7.60 \pm 0.25^{\mathrm{bc}}$ \\
& 6 & $8.50 \pm 0.46^{\mathrm{a}}$ & $8.00 \pm 0.43^{\mathrm{b}}$ & $8.20 \pm 0.46^{\mathrm{b}}$ & $8.00 \pm 0.63^{\mathrm{b}}$ & $8.03 \pm 1.24^{\mathrm{ab}}$ \\
\multirow{3}{*}{ Rice syrup } & 10 & $8.50 \pm 0.41^{\mathrm{a}}$ & $8.50 \pm 0.55^{\mathrm{a}}$ & $8.60 \pm 0.29^{\mathrm{a}}$ & $8.50 \pm 0.35^{\mathrm{a}}$ & $8.27 \pm 0.23^{\mathrm{a}}$ \\
& 3 & $8.00 \pm 0.55^{\mathrm{b}}$ & $6.50 \pm 0.27^{\mathrm{e}}$ & $7.40 \pm 0.20^{\mathrm{c}}$ & $6.50 \pm 0.27^{\mathrm{e}}$ & $7.08 \pm 0.51^{\mathrm{d}}$ \\
& 6 & $7.50 \pm 0.30^{\mathrm{c}}$ & $7.00 \pm 0.36^{\mathrm{d}}$ & $7.50 \pm 0.29^{\mathrm{c}}$ & $7.00 \pm 0.27^{\mathrm{d}}$ & $7.42 \pm 0.19^{\mathrm{cd}}$ \\
Sorbitol & 10 & $7.40 \pm 0.24^{\mathrm{c}}$ & $7.50 \pm 0.33^{\mathrm{c}}$ & $8.00 \pm 0.31^{\mathrm{b}}$ & $7.50 \pm 0.50^{\mathrm{c}}$ & $7.55 \pm 0.50^{\mathrm{cd}}$ \\
& 3 & $7.50 \pm 0.28^{\mathrm{c}}$ & $6.40 \pm 0.30^{\mathrm{e}}$ & $7.50 \pm 0.29^{\mathrm{c}}$ & $6.40 \pm 0.21^{\mathrm{e}}$ & $7.10 \pm 0.47^{\mathrm{d}}$ \\
& 6 & $7.30 \pm 0.35^{\mathrm{cd}}$ & $7.00 \pm 0.17^{\mathrm{d}}$ & $8.00 \pm 0.31^{\mathrm{b}}$ & $6.50 \pm 0.45^{\mathrm{e}}$ & $7.42 \pm 0.19^{\mathrm{cd}}$ \\
& 10 & $7.00 \pm 0.37^{\mathrm{d}}$ & $7.50 \pm 0.33^{\mathrm{c}}$ & $8.50 \pm 0.36^{\mathrm{a}}$ & $7.00 \pm 0.27^{\mathrm{d}}$ & $7.53 \pm 0.47^{\mathrm{cd}}$ \\
\hline
\end{tabular}

${ }^{\mathrm{a}-\mathrm{f}}$ Means \pm standard deviation in the same row with different superscripts are significantly different at $\mathrm{p}<0.05$. 
duck jerky. Results indicate that application of honey effectively enhances colour, flavour, tenderness, sweetness, and overall acceptability. The unique flavour, sweetness, and dark red-yellow colour resulting from honey treatment played a positive role in the sensory evaluation of restructured duck jerky, distinguishing it from other humectant treatments. Accordingly, honey might be a strongly recommendable alternative natural humectant in place sorbitol in restructured duck jerky.

\section{CONCLUSION}

This study was conducted in order to examine the physicochemical characteristics of duck jerkies treated with honey and rice syrup, and evaluate their feasibility as replacements for sorbitol. The use of natural humectants in this study positively affected the chemical properties of duck jerky, especially at higher concentrations. The samples treated with honey had better properties than those treated with the same concentration of rice syrup and sorbitol. Therefore, honey, has the potential to be used as a natural humectant and replaces the use of sorbitol. Further research is needed to study the ability of these humectants to extend the shelf life of restructured duck jerky.

\section{CONFLICT OF INTEREST}

We certify that there is no conflict of interest with any financial organization regarding the material discussed in the manuscript.

\section{ACKNOWLEDGMENTS}

This study was supported by the Leaders in IndustryUniversity Cooperation Project, Ministry of Education (MOE) and the National Research Foundation (NRF), and the Research Fund of Gangneung-Wonju National University, Korea.

\section{REFERENCES}

Antony, S., J. R. Rieck, and P. L. Dawson. 2000. Effect of dry honey on oxidation in turkey breast meat. Poult. Sci. 79:18461850.

AOAC. 2007. Official Methods of Analysis. 18th Ed. Association of Official Analytical Chemists, Washington, DC.

Banwart, G. 1989. Basic Food Microbiology. 2nd Ed. AVI Publishing Company Inc., Westport, CT, USA.

Bertoncelj, J., U. Doberšek, M. Jamnik, and T. Golob. 2007. Evaluation of the phenolic content, antioxidant activity and colour of Slovenian honey. Food Chem. 105:822-828.

Borneman, D. L., S. C. Ingham, and C. Ane. 2009. Predicting growth-no growth of Staphylococcus aureus on vacuumpackaged ready-to-eat meats. J. Food Prot. 72:539-548.
Brewer, M. S., J. Jensen, A. A. Sosnicki, B. Fields, E. Wilson, and F. K. McKeith. 2002. The effect of pig genetics on palatability, color and physical characteristics of fresh pork loin chops. Meat Sci. 61:249-256.

Chang, S. F., T. C. Huang, and A. M. Pearson. 1996. Control of the dehydration process in production of intermediate-moisture meat products: a review. Adv. Food Nutr. Res. 39:71-161.

Cho, E. J. and J. E. Lee. 2000. The Effect of addition of kinds of sugar and drying method on quality and storage characteristics of beef jerky. Korean J. Soc. Food Sci. 16:511-520.

Culler, R. D., F. C. Parrish, G. C. Smith, and H. R. Cross. 1978. Relationship of myofibril fragmentation index to certain chemical, physical, and sensory characteristics of bovine longissimus muscle. J. Food Sci. 43:1177-1180.

Emerton, V. and E. Choi. 2008. Essential Guide to Food Additives. 3rd Ed. Leatherhead Food International Ltd., Surrey, UK.

FAO. 1996. Value-added products from beekeeping. In: FAO Agricultural Services Bulletin No. 124. http://www.fao.org/ docrep/w0076e/w0076e00.htm. Accessed February 4, 2015.

FAO. 2015. Meat Consumption. http://www.fao.org/ag/againfo/ themes/en/meat/background.html. Accessed April 31, 2015.

Faucitano, L., P. Y. Chouinard, J. Fortin, I. B. Mandell, C. Lafrenière, C. L. Girard, and R. Berthiaume. 2008. Comparison of alternative beef production systems based on forage finishing or grain-forage diets with or without growth promotants: 2. Meat quality, fatty acid composition, and overall palatability. J. Anim. Sci. 86:1678-1689.

Gheldof, N. and N. J. Engeseth. 2002. Antioxidant capacity of honeys from various floral sources based on the determination of oxygen radical absorbance capacity and inhibition of in vitro lipoprotein oxidation in human serum samples. Agric. Food Chem. 50:3050-3055.

Gleiter, R. A., H. Horn, and H. D. Isengard. 2006. Influence of type and state of crystallisation on the water activity of honey. Food Chem. 96:441-445.

Han, D. J., J. H. Choi, Y. S. Choi, H. Y. Kim, S. Y. Kim, H. W. Kim, H. K. Chung, and C. J. Kim. 2011. Effect of konjac, isolated soy protein, and egg albumin on the quality properties of semi-dried chicken jerky. Korean J. Food Sci. Anim. Resour. 31:183-191.

Hu, X., X. Xu, Z. Jin, Y. Tian, Y. Bai, and Z. Xie. 2011. Retrogradation properties of rice starch gelatinized by heat and high hydrostatic pressure (HHP). J. Food Eng. 106:262-266.

Jaturasitha, S., T. Srikanchai, M. Kreuzer, and M. Wicke. 2008. Differences in carcass and meat characteristics between chicken indigenous to northern Thailand (black-boned and Thai native) and imported extensive breeds (Bresse and Rhode Island Red). Poult. Sci. 87:160-169.

Kim, C. J. and E. S. Lee. 2003. Effects of quality grade on the chemical, physical and sensory characteristics of Hanwoo (Korean native cattle) beef. Meat Sci. 63:397-405.

Kim, Y. J., K. E. Hwang, F. Y. He, and C. J. Kim. 2014. Effect of different drying conditions on quality characteristics of restructured duck tender jerky. In: Proceedings of the 2014 International Conference on Food and Nutrition Technology, Singapore, Singapore. pp. 36-40.

Konieczny, P., J. Stangierski, and J. Kijowski. 2007. Physical and chemical characteristics and acceptability of home style beef 
jerky. Meat Sci. 76:253-257.

Lee, S. W. and C. S. Kang. 2003. Effects of moisture content and drying temperature on the physicochemical properties of ostrich jerky. Food/Nahrung 47:330-333.

Leistner, L. 1985. Hurdle technology applied to meat products of the shelf stable product and intermediate moisture food types. In: Properties of Water in Foods (Eds. D. Simatos, and J. L. Multon). Springer Netherlands, Netherlands. pp. 309-329.

Malika, N., F. Mohamed, and E. A. Chakib. 2005. Microbiological and physico-chemical properties of Moroccan honey. Int. J. Agric. Biol. 2:100-104.

McClure, P. J., M. B. Cole, and J. P. P. M. Smelt. 1994. Effects of water activity and $\mathrm{pH}$ on growth of Clostridium botulinum. J. Appl. Bacteriol. 76:105S-114S.

McKibben, J. and N. J. Engeseth. 2002. Honey as a protective agent against lipid oxidation in ground turkey. J. Agric. Food Chem. 50:592-595.

Meilgaard, M., G. Civille, and B. Carr. 1999. Sensory Evaluation Techniques. 2nd Ed. CRC Press, Boca Raton, FL, USA.

Michio, M., N. Teruhiro, U. Raizaburo, G. Ichiro, and Y. Mamoru. 1987. Humectants improve myosin extractability and water activity of raw, cured intermediate moisture meats. Meat Sci. 20:179-194.

Nagai, T., R. Inoue, N. Kanamori, N. Suzuki, and T. Nagashima. 2006. Characterization of honey from different floral sources. Its functional properties and effects of honey species on storage of meat. Food Chem. 97:256-262.
Newman, A. W., I. M. Vitez, R. L. Mueller, C. C. Kiesnowski, W. P. Findlay, C. Rodriguez, M. Davidovich, and G. McGeorge. 1999. Sorbitol. In: Analytical Profiles of Drug Substances and Excipients (Ed. G. B. Harry). Academic Press, Milford, NJ, USA. pp. 459-502.

Ogahara, T., M. Ohno, M. Takayama, K. Igarashi, and H. Kobayashi. 1995. Accumulation of glutamate by osmotically stressed Escherichia coli is dependent on pH. J. Bacteriol. 177: 5987-5990.

Quinton, R. D., D. P. Cornforth, D. G. Hendricks, C. P. Brennand, and Y. K. Su. 1997. Acceptability and composition of some acidified meat and vegetable stick products. J. Food Sci. 62: 1250-1254.

Rajalakshmi, D. and S. Narasimhan. 1996. Food antioxidants: Source and methods of evaluations. In: Food Antioxidants (Eds. D. L. Madhavi, S. S. Deshpande, and D. K. Salunlhe). Marcel Decker Inc., New York, NY, USA. pp. 73-82.

Sindelar, J. J., M. J. Terns, E. Meyn, and J. A. Boles. 2010. Development of a method to manufacture uncured, nonitrate/nitrite-added whole muscle jerky. Meat Sci. 86:298-303.

Sinhuber, R. and T. Yu. 1977. The 2-thiobarbituric acid reaction, an objective measure of the oxidative deterioration occurring in fats and oil. J. Jap. Soc. Fish Sci. 26:259-267.

SPSS. 2012. Statistical Package for Social Sciences for Windows (version 12.0). SPSS Inc., Chicago, IL, USA.

Wongwiwat, P. and S. Wattanachant. 2010. Effect of sweeteners on physical attributes and microstructure of sweet-dried chicken meat. In: Proceedings of the 2010 The 3rd International PSUUNS Conferences on Bioscience, Songkhla, Thailand. pp. 6770. 